\title{
Vi udvider!
}

Velkommen til et nyt og spændende nummer af Dansk Universitetspædagogisk Tidsskrift!Vi er et forholdsvist ungt tidsskrift med kun 3 år på bagen og søger derfor måske $i$ højere grad end mere etablerede tidsskrifter at afklare vores identitet og vores særlige berettigelse i rækken af mulige kanaler, hvorigennem ansatte på højere læreanstalter kan formidle deres viden. Det nye, spændende og identitetsafklarende i dette nummer består $i$ en præcisering og med tiden udvidelse af vore artikelkategorier.Vi har i længere tid været kede af at skulle afvise at reviewe de mange artikler, vi fik ind, som handlede om god undervisningspraksis og reflekterede erfaringsudvekslinger.Vi var kede af det, fordi vi mente at et tidsskrift som DUT - som det mindste skulle slå et slag for en universitetsansats ret og pligt til også at fokusere på undervisning og derfor anerkende og meritere artikler om undervisningspraksis på lige fod med artikler om forskning i undervisning. Derfor vil du i dette nummer finde en række artikler, som er reviewede og som hører til i kategorien, »Formidling af god undervisningspraksis". I skrivende stund opererer vi altså med to artikelkategorier: Formidling af god undervisningspraksis og Rapportering af forskningsprojekter, og forventer i forhold til deadline for DUT9 (1. oktober 2009) at være klar med endnu en kategori med overskriften, »Analyse og debat", som ligeledes vil indeholde reviewede artikler. En udvidelse af tilbuddet om review (og dermed meritering) af artikler inden for flere kategorier kræver naturligvis en udvidelse af vores vurderingskriterier. Disse kan findes på tidsskriftets hjemmeside, www.dun-net.dk/tidsskrift.

Når disse linjer læses, står vi på tærsklen til den årlige DUN-konference. Det bringer os til at minde om, at hvert andet nummer af DUT som udgangspunkt vil være en slags opfølgning på konferencen - det være sig enten som dokumentation af diverse oplæg fra konferencen, som er blevet til artikler, eller artikler, som på anden måde er affødt af konferencen og dens tema. Deadline for artikler til DUT8 er d. 5. juni 2009, så der skal ikke være langt fra tanke til handling, hvis du overvejer at skrive en artikel på baggrund af konferenceoplevelser!
Den omtalte konference bliver ligeledes en festligholdelse af 15-året for DUN's eksistens, og helt i jubilæumsånden har redaktionen valgt at indlede dette nummer med en artikel af DUNs formand, Thomas Harboe, som i artiklen, Dansk Universitetspædagogisk Netværk (DUN) - for, nu og fremover, tegner et historisk billede af DUN gennem de seneste 15 år. Det fremgår, hvorledes DUN har udviklet sig fra at være en græsrodsbevægelse til i dag at være en strømlinet organisation med vedtægter, opdateret hjemmeside, lang medlemsliste, fast årlig konference, internationalt samarbejde og et tidsskrift. Endvidere tegnes der et billede af, hvorfor den politiske diskurs for undervisningen nødvendiggør, at der er et talerør som DUN, hvor uddannelsesudviklere og undervisere kan hente inspiration og debattere.

Som nævnt indeholder dette nummer en række artikler i kategorien "Formidling af god undervisningspraksis«.Vi lægger ud med Jeppe Bundsgaards artikel, Krydsmodel for undervisningstilrettelæggelse, som introducerer en måde at sikre sig, at der i et givent undervisningsforløb er tilstrækkeligt varierede læringsmuligheder for de studerende. JB beskriver, hvordan de studerende $i$ et varieret undervisningsforløb på DPU vurderer deres eget læringsudbytte. Bl.a. fremhæves at forberedelsen til eksamen har været læringsmæssigt udbytterigt.

Denne - væsentlige - del af et undervisningsforløb har man et andet sted på DPU eksperimenteret med. Jacob Krause-Jensen redegør i artiklen, Syv fluer med et smæk, for, hvordan man har praktiseret maktiv deltagelse« som eksamensform, således at de studerende til hver undervisningsgang har skullet skrive et mindre analysepapir og har fået elektronisk feedback. JK-J analyserer og diskuterer eksamensformer og argumenterer for dens pædagogiske fordele.

En anden måde at variere sin undervisning på er i den enkelte undervisningsseance at appellere til forskellige læringsstile. I Ny vin på gamle flasker: Læringsstile $i$ undervisningen på de videregående uddannelser redegør Karen M. Lauridsen og Ole Lauridsen for Dunn \& Dunns læringsstilsbegreb og 
efterfølgende for forskning, der beskæftiger sig med læringsstilskonceptets effekt. Forfatterne følger dette op med praksiseksempler, hvor konceptet er taget i brug, og foreslår afslutningsvis, at der igangsættes forskning, der kan bidrage til forklaringer på, hvorfor det virker.

Tidsskriftet rummer også artikler i kategorien »Rapportering af forskningsprojekter«. I den første artikel, Gruppebaseret eller individuel projekteksamen fordele og ulemper, præsenterer Anette Kolmos og Jette Holgaard resultater fra en spørgeskemaundersøgelse blandt studerende, vejledere og censorer med tilknytning til Aalborg Universitet. Resultaterne viser, at den individuelle eksamensform ikke rummer den samme mulighed for at teste centrale projektkompetencer, og den respons, de studerende făr til deres projekt, vurderes som mindre tilfredsstillende, hvorfor didaktiske argumenter for den individuelle eksamensform vurderes at være svære at finde. Endvidere viser undersøgelsen, at majoriteten blandt de mere end 1000 studerende, eksaminatorer og censorer, der besvarede undersøgelsen, ville foretrække en gruppebaseret projekteksamen.

Ligeledes fra Aalborg Universitet og ligeledes en komparativ undersøgelse, men i denne artikel om undervisningen: Tina Bering Keiding præsenterer i Problemorientering set fra tre uddannelsers perspektiv undervisningsformen problemorienteret projektarbejde, som den iagttages af deltagerne på tre uddannelser på De Ingeniør, Natur- og Sundhedsvidenskabelige Fakulteter på Aalborg Universitet (AAU). TBK konkluderer, at problemorientering i klassisk forstand ikke har nogen betydning på de tre uddannelser. To af uddannelserne finder derimod problembegrebet problematisk i forhold til uddannelsens faglighed.

Hvor TBK undersøger problemorienteringen på et overordnet uddannelsesniveau, beskæftiger næste artikel, Har du et problem?, sig med problemorienteringen på studenterniveau. Sanne Knudsen har undersøgt, hvordan universitetsstuderende (på RUC) opfatter og praktiserer problemorientering i deres rapporter. Undersøgelsen viser, at de studerende ofte opfatter "problemet" som den studerendes egen mangel på viden om et emne. SK giver - uden at afvise de studerendes subjektive tilgang - forskellige forslag til at fremme de studerendes videre forståelse og praksis mht. problemorientering.

Sluttelig bringer vi to boganmeldelser af litteratur med universitetspædagogisk interesse.

Deadlines for de kommende numre af Dansk Universitetspædagogisk Tidsskrift kan findes på hjemmesiden, www.dun-net.dk/tidsskrift, hvor også retningslinjer og manuskriptvejledninger ligger. Send dit artikelforslag tildut@dun-net.dk. God skrive- og læselyst! 